\title{
Nutritional Contribution of Some Senegalese Forest Fruits Running across Soudano-Sahelian Zone
}

\author{
Nicolas Cyrille Ayessou ${ }^{1 *}$, Cheikh Ndiaye ${ }^{2}$, Mady Cissé ${ }^{1}$, Mathieu Gueye ${ }^{3}$, Mama Sakho ${ }^{1}$ \\ ${ }^{1}$ Laboratoire de Formation Continue en Industries Agroalimentaires, Ecole Supérieure Polytechnique, Université Cheikh Anta Diop, \\ Dakar, Sénégal; ${ }^{2}$ Laboratoire des Biotoxines et Contrôle des Aliments, Institut de Technologie Alimentaire (ITA), Dakar, Sénégal; \\ ${ }^{3}$ Département de Botanique et Géologie, Institut Fondamental d'Afrique Noire Cheikh Anta Diop, Dakar, Sénégal. \\ Email: nayessou@yahoo.fr
}

Received May $12^{\text {th }}, 2011$; revised July $3^{\text {rd }}, 2011$; accepted July $9^{\text {th }}, 2011$.

\begin{abstract}
As a good food supply for the local people in various Senegalese regions, the forest fruits are becoming very important. They are using between foods or main condiment for dishes in many part of Africa. These fruits represent non negligible sources of vitamins, carbohydrates and minerals. Instead of more commercialized species such as Adansonia digitata L., Detarium senegalensis J. F. Gmel., Saba senegalensis (A.DC.) Pichon, Tamarindus indica L., this article focused on nutritional values of other fruits with little interest or neglected. These species were Ficus gnaphalocarpa, $L$., Cordyla pinnata (Lepr. ex A.Rich.) Milne-Redh and Icacina senegalensis, harvested in soudano-sahelian zone; while Sarcocephalus latifolius (Sm.) E. A. Bruce belongs to Sudanese zone. The fruit pulps were isolated and freeze dried before analysis. The results showed that acidity, vitamin $C$ and total minerals were significantly different from one fruit to another. S. latifolius with the highest acidity content $(402.43 \mathrm{mg} / 100 \mathrm{~g})$ and best vitamin C content if $1488 \mathrm{mg} / 100 \mathrm{~g}$ were found. Also as results, S. latifolius provided high protein content nearby the $20 \%$. The caloric contributing ( $\mathrm{kcal} / 100 \mathrm{~g}$ ) were 102.5, 177 and 132 respectively for F. gnaphalocarpa, C. pinnata, and S. latifolius. The ash contents were the same for all species (4.5\%), indicating the richness in mineral elements. Furthermore, all species in this study were good sources of iron, copper and zinc. However, small amounts of sodium were noticed in all samples. Analysis of total sugars and their profile showed that I. senegalensis and C. pinnata were more appreciated. These results predicted the useful incomes for forest fruits in human being. Lot of medicinal virtues has been recognized from these fruits. The increase in value and the preservation of the biodiversity are necessary particularly for C. pinnata which presents a serious threat because of the strong income for wood production.
\end{abstract}

Keywords: Cordyla pinnata, Sarcocephalus latifolius, Ficus gnaphalocarpa, Icacina senegalensis, Nutritional Composition, Senegal

\section{Introduction}

In Sahel zone particularly Senegal, despite protection directive; development programs (FAO, 1999a [1]; Ministère, 2005 [2]) and some domestication endeavors (Kalinganire, Weber, Uwamariya, \& Kone, 2007 [3]; Koné, Kalinganire, \& Doumbia, 2009 [4]); the natural forested plantings are constantly degraded and the edible resulted products are becoming rare (FAO, 1999b [5]; Perera \& Baldwin, 2001 [6]). The reasons of this unusualness is essentially due to anthropogenic pressure (Faye, Diatta, Samba, \& Lejoly, 2009 [7]). However in Senegal, some results showed that the annual regression rhythm during 1991-1999 was attenuated (Allemande, 2005 [8]). Many studies showed the various potentialities of forest plants in the country planning (Faye, Diatta, Samba, \& Lejoly, 2009 [7]), soils fortification (Giner et al., 2000 [9]; Samba, C. Camire, \& Margolis, 2001 [10]), combustibles source (Allemande, 2005) [8], field sown with fodder crop source (Samba, C. Camire, \& Margolis, 2001) [10], pharmacological use (Keita, Arnason, Baum, \& Marles, 1999 [11]; N'Diaye, Kéita, \& Martin, 2003 [12]; Soloviev, Niang, Gaye, \& Totte, 2004; UICN, 2006 [13]) and food (FAO, 1999 [1], 1999 [5]).

These forest plants are socio-economically important 
and non-neglected. The most exploited organs are the fruit. In Senegal, takings from forest fruits in 1990 represented 30\%, about 457,000 Euros (Itef, 1991) [14].

The lists of forest fruits spontaneously used and commercialized have been given in many studies and protecttion programs for forest plants (Ambé, 2001 [15]; N'Diaye, Kéita, \& Martin, 2003 [12]; UICN, 2006 [16]). Nevertheless, the nutritional interest is not specified excepted for some major fruits of high economic importance including Adansonia digitata (Cissé et al., 2009 [17]; Gabar, Sakho, Dornier, Cissé, \& Reynes, 2006 [18]), Ziziphus mauritiana (Muchuweti, Zenda, Ndhlala, \& Kasiyamhuru, 2005 [19]; Ugese, Baiyeri, \& Mbah, 2008 [20]), Vitellaria paradoxa (Ugese, Baiyeri, \& Mbah, 2008) [20], Balanites aegyptiaca (Abdel-Rahim, El-Saadany, \& Wasi, 1986) [21] and Tamarindus indica (Ugese,
Baiyeri, \& Mbah, 2008) [20].

Any result on nutritional aspect of the forest fruits, such as Ficus gnaphalocarpa L., Cordyla pinnata (Lepr. ex A. Rich.) Milne-Redh, Sarcocephalus latifolius (Sm.) E. A. Bruce and Icacina senegalensis Adr. Juss., concerning this article has been published or reported. The aim of the article paper is to (1) study the nutritional values of these forest fruits by biochemical analysis, and (2) give off some possible ascribable applications.

\section{Materials and Methods}

\subsection{Biological Materials}

Matured sample fruits (Table 1) were harvested during their maturation periods and were made up into different batches. Species of fruits used were Ficus gnaphalo-

Table 1. The different samples used in this work.

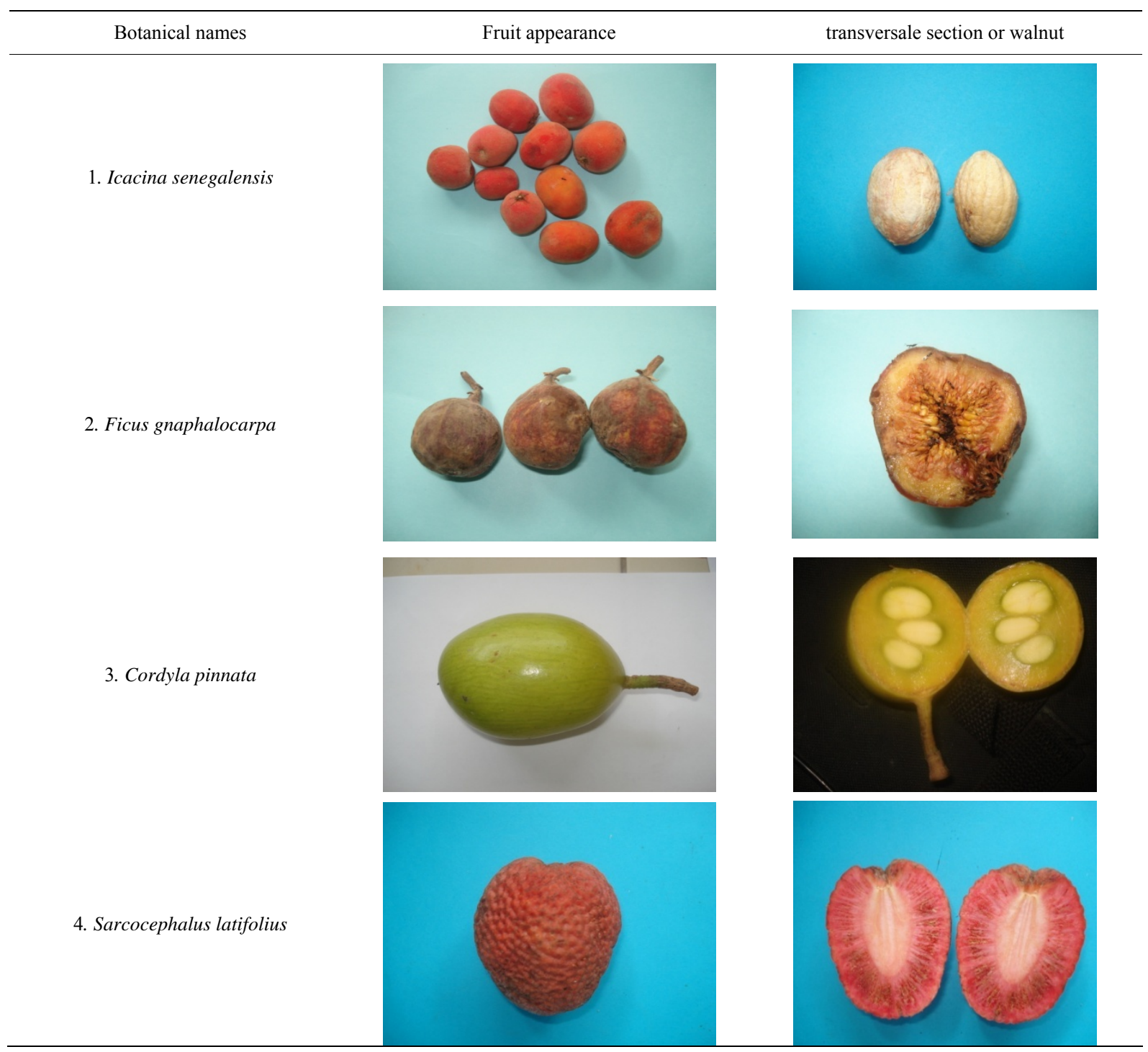


carpa, L., Cordyla pinnata (Lepr. ex A.Rich.) MilneRedh. and Icacina senegalensis Adr. Juss; all harvested in Kaffrine's region (center of Senegal), in soudano-sahélienne zone. The species of Sarcocephalus latifolius (Sm.) E.A. Bruce were from Kédougou and Ziguinchor regions, south of Senegal (Sudanese zone).

\section{Sample Preparations}

Acidity dosage, vitamin $\mathrm{C}$ dosage, proteins dosage, and total minerals determination were realized on pulps isolated in crude state. Other samples were used after removing their pericarps and the edible parts were freeze drying for lipids dosage, soluble sugars dosage, simple sugars and trace elements' determination.

\subsection{Methods}

\subsubsection{Volumetric Dosages}

The acidity was determined according to the normalized method NF V05-101 (Afnor, 1982) [22] the vitamin C by using the method of Dichloro-2,6 Phenol Indo Phenol referenced NF V 76-005 (Afnor, 1982) [22]. The nitrogen dosage by the method of Kjeldhal NF 03-050 (Afnor, 1982) [22] and proteins were calculated using 5.7 as coefficient. The total minerals were determined after 3 hours incineration at $550^{\circ} \mathrm{C}$ according to V76-101 method (Afnor, 1982) [22].

\subsubsection{Sugar Composition}

The sugar composition was determined by Dionex DX600 HPLC, after using a volume of $80 \%$ ethanol for extraction. A CarboPac MA1 $(4 \times 250 \mathrm{~mm} ; 7.5 \mu \mathrm{m})$ colon was used, and 0.6 to 0.8 of $\mathrm{NaOH}$ solution, with a 0.4 $\mathrm{mL} / \mathrm{min}$ constituted the mobile phase.

\subsubsection{Minerals Determination}

After dry way mineralization at $500^{\circ} \mathrm{C}$, then desilication with fluorihydric acid of sample weights, the detection of sodium, potassium, calcium, magnesium, phosphorus, copper, zinc and iron were realized by using a spectrophotometer of plasma radiation with inductive coupling of Varian-vista type.

\subsubsection{Statistic Analysis}

The analyses were repeated three times. The three sets of data were analyzed by SAS software (version 8.1, 2000; SAS Institute, Inc., Cary, NC).

\section{Results and Discussion: Nutritional Composition of Different Fruits Samples}

\subsection{Total Soluble Sugars and Simple Sugars}

Table 2 shows the amounts of total soluble sugars in different forest fruits' samples used in this work.

The contents of total soluble sugars in these matured fruits are variable and significantly different $(p<0.05)$. Species of $I$. senegalensis and $C$. pinnata own high content of sugars $60.93 \mathrm{~g} / 100 \mathrm{~g}$ and 50.93 (Table 2) respecttively in dry matter compared to $F$. gnaphalocarpa $(18.83 \mathrm{~g})$ and S. latifolius $(24.53 \mathrm{~g})$. The same trend was observed for fructose and saccharose except for glucose in which the content is statistically identical in C. pinnata and S. latifolius species $(5.70$ and $5.97 \mathrm{~g} / 100 \mathrm{~g}$ in dry matter). The same conclusion in F. gnaphalocarpa and $S$. latifolius for the fructose contents of 9.87 and $9.80 \mathrm{~g} / 100$ $\mathrm{g}$ in dry matter respectively, was observed. Nevertheless, it's important to mention that saccharose represents the essential total soluble sugar in C. pinnata $(80.10 \%)$, S. latifolius $(43.62 \%)$ and I. senegalensis $(36.71 \%)$ compared to F. gnaphalocarpa in which only $4.05 \%$ of this disaccharide was found. In this last, fructose and glucose respectively $8.8 \pm 0.70 \mathrm{~g} / 100 \mathrm{~g}$ in dry matter (if $52.41 \%$ of total sugar) and $9.87 \pm 0.67 \mathrm{~g} / 100 \mathrm{~g}$ in dry matter (if $46.73 \%$ of total sugar) were obtained. Furthermore, $C$. pinnata and S. latifolius contain high amounts of total sugars compared to Adansonia digitata specie (20\% and $32 \%$ ) [23]. Moreover, compared to Ziziphus mauritiana [24], the fruit of I. senegalensis provide the same amount of sugar (between $56 \%$ and $65 \%$ ). However, saccharose absence can be noticed in Z. mauritiana, replaced by galactose [25]. From these results, Cordyla pinnata can be selected as a good source of saccharose for food industry in comparison to sugar cane and beet. Furthermore, I. senegalensis constitute an advantage of diversified reducing sugars' production (glucose and fructose) as well as non reducing sugars (saccharose).

Table 2. Total soluble sugars in different samples.

\begin{tabular}{ccccc}
\hline Samples & Total soluble sugars $\left(\mathrm{g} / 100 \mathrm{~g}^{*}\right)$ & Glucose $(\mathrm{g} / 100 \mathrm{~g} *)$ & Fructose $\left(\mathrm{g} / 100 \mathrm{~g}^{*}\right)$ & Saccharose $\left(\mathrm{g} / 100 \mathrm{~g}^{*}\right)$ \\
\hline F. gnaphalocarpa & $18.83 \pm 1.40 \mathrm{~d}$ & $8.8 \pm 0.70 \mathrm{~b}$ & $9.87 \pm 0.67 \mathrm{~b}$ & $0.73 \pm 0.06 \mathrm{~d}$ \\
I. senegalensis & $60.93 \pm 1.22 \mathrm{a}$ & $16.80 \pm 1.74 \mathrm{a}$ & $19.00 \pm 1.73 \mathrm{a}$ & $22.37 \pm 2.33 \mathrm{~b}$ \\
C. pinnata & $50.93 \pm 3.56 \mathrm{~b}$ & $5.70 \pm 0.17 \mathrm{c}$ & $7.17 \pm 0.13 \mathrm{c}$ & $40.80 \pm 1.37 \mathrm{a}$ \\
S. latifolius & $24.53 \pm 1.27 \mathrm{c}$ & $5.97 \pm 0.21 \mathrm{c}$ & $9.80 \pm 0.44 \mathrm{~b}$ & $10.7 \pm 0.82 \mathrm{c}$ \\
\hline
\end{tabular}

*In dry matter; values in columns labeled with different letters are significantly different $(p<0.05)$. 


\subsection{Proteins Content, Minerals, Vitamin $C$ and Acidity}

Table 3 shows the amounts of proteins, vitamins C, acidity (expressed as citric acid) and minerals.

Comparison between protein contents shows that $S$. latifolius present the best contributing of proteins by $17.02 \%$. This rate is significantly higher when compared to $C$. pinnata $(11.15 \%)$ and $F$. gnaphalocarpa $(10.36 \%)$. In fact, the protein content of $S$. latifolius (belonging to our fruits' target) is superior enough compared to common strawberry fruit $(0.73 \%)$ [26], Z. mauritiana $(11.8 \%$ MS) [24], A. digitata (between 1.8 and 2.7\%) [23]. However, this amount of $S$. latifolius protein remains relatively low compared to Maerua pseudopetalosa (22.06\%), a forest fruit [27]. C. pinnata and F. gnaphalocarpa protein contents are significantly identical $(p<0.05)$.

The mineral contents are inversely proportional to the protein contents. Thus, S. latifolius presents the lowest value $(3.38 \%)$ compared to F. gnaphalocarpa and C. pinnata respectively 4.63 and 4.91 . The acidity, vitamin $\mathrm{C}$ and total minerals are significantly different form one sample to another. However, S. latifolius with the highest acidity content $(402.43 \mathrm{mg} / 100 \mathrm{~g})$ holds the best vitamin $\mathrm{C}$ content (1488 mg/100 g from Table 3); this richness is close to Acerola Malpighia punicifolia (1800 mg/100 g) [28] classified as the second fruit with highest vitamin C after camu-camu Myrciaria dubia [29]. In many local fruits including Z. mauritiana, A. digitata, Hibiscus sabdariffa calyx, and Detarium senegalensis, the vitamin $\mathrm{C}$ contents are respectively $405 \mathrm{mg} / 100 \mathrm{~g}$ [24]; 125 to 312 $\mathrm{mg} / 100 \mathrm{~g}$ [23]; 58 to $63 \mathrm{mg} / 100 \mathrm{~g}$; and $967 \mathrm{mg} / 100$ [30]. The consumption of these fruits can cover the daily intake of vitamin C (between $42 \mathrm{mg} /$ day and 93) [28] as shown in wild Thailand's fruits [31]. From the later reference, we are leading researches on the antioxidant activities which can be improved by crudes fibers, total polyphenol content, total flavonoids in these forest fruits. However, the moderated consumption of S. latifolius has been suggested because, an exceed consumption of vitamin $\mathrm{C}$ engenders some gust intestine troubles [32], some oxalate crystal formation in the urinary system [33] and indeed red globulins hemophiliac [34].

\subsection{Mineral Contents}

The results of mineral contents in different samples are mentioned in Table 4.

Excepted for potassium (in Table 4), S. latifolius, F. gnaphalocarpa and I. senegalensis own high copper content (between 8.2 to $9.4 \mathrm{mg} / \mathrm{kg}$ ), iron content (from range of 54.7 to $81.8 \mathrm{mg} / \mathrm{kg}$ in dry matter) and zinc content (between 10.1 to $25.6 \mathrm{mg} / \mathrm{kg}$ ). Compared to C. pinnata, a weak profile of calcium elements, magnesium, copper, iron, and zinc was observed. Nevertheless, on one hand abnormal values for iron were noticed in $C$. pinnata samples (19 mg/kg in dry matter) and S. latifolia $(184 \mathrm{mg} / \mathrm{kg}$ in dry matter) samples; on another hand high deviation of zinc content in C. pinnata $(3.9 \mathrm{mg} / \mathrm{kg}$ in dry matter) was also observed. The same results were obtained after many repetitions (three).

Sarcocephalus latifolius fruits contain more phosphorrus $(0.214 \mathrm{~g}$ to $0.209 \mathrm{~g})$ compared to other fruits in this study. The high contents of potassium were encountered in Cordyla pinnata and Ficus gnaphalocarpa (respectively $2.471 \mathrm{~g}$ and $2.333 \mathrm{~g}$ ). Ficus gnaphalocarpa and Sarcocephalus latifolius contain the highest values of Calcium contents (0.612 g and $0.496 \mathrm{~g})$ and Magnesium $(0.210 \mathrm{~g} ; 0.155 \mathrm{~g})$. For sodium, the more important content were observed in Ficus gnaphalocarpa $(0.028 \mathrm{mg})$ and Icacina senegalensis (0.018 mg) but still low compared to the reference. Finally for the copper $(\mathrm{Cu})$, only Cordyla pinnata gave relatively low values, between 3.4 and $4.1 \mathrm{mg}$. The comparative table with other known forest fruits (Table 5) allows globally to deduce that all fruits in this study are good sources of mineral contents characterized by their richness in copper, iron and zinc; only sodium present a low content.

\section{Conclusions}

The results from this study show the important role expected from these forest fruits in the food equilibrium of local population in the different exploited zones. In fact, these fruits can cover the daily intake of vitamin $\mathrm{C}$ espe-

Table 3. Amounts of proteins, vitamins $\mathrm{C}$, acidity and minerals in the different samples.

\begin{tabular}{ccccc}
\hline Samples & Proteins $\mathrm{N} \times 5.7(\% \mathrm{DM})$ & Acidity $(\mathrm{mg} / 100 \mathrm{~g}) *$ & ${\text { Vitamin C }(\mathrm{mg} / 100 \mathrm{~g})^{*}}^{\text {Mineral contents }(\mathrm{g} / 100 \mathrm{~g}){ }^{*}}$ \\
\hline F. gnaphalocarpa & $10.36 \pm 0.08 \mathrm{~b}$ & $70.2 \pm 0.26 \mathrm{c}$ & $487 \pm 0.01 \mathrm{c}$ & $4.63 \pm 0.12 \mathrm{~b}$ \\
I. senegalensis & $\mathrm{nd}$ & $\mathrm{nd}$ & $\mathrm{nd}$ & $\mathrm{nd}$ \\
C. pinnata & $11.15 \pm 0.04 \mathrm{~b}$ & $87.33 \pm 0.29 \mathrm{~b}$ & $965 \pm 0.13 \mathrm{~b}$ & $4.91 \pm 0.08 \mathrm{a}$ \\
S. latifolius & $17.02 \pm 1.84 \mathrm{a}$ & $402.43 \pm 0.40 \mathrm{a}$ & $1488 \pm 0.33 \mathrm{a}$ & $3.38 \pm 0.11 \mathrm{c}$ \\
\hline
\end{tabular}

DM: dry matter; nd: not determined; Values in columns labeled with different letters are significantly different $(p<0.05) ; *$ results expressed as the original matter. 
Table 4. Minerals contents.

\begin{tabular}{ccccccccc}
\hline & $\mathbf{P}$ & $\mathbf{K}$ & $\mathbf{C a}$ & $\mathbf{M g}$ & $\mathbf{N a}$ & $\mathbf{C u}$ & $\mathbf{F e}$ & $\mathbf{Z n}$ \\
\hline Samples & & & $\mathrm{g} / 100 \mathrm{~g}^{*}$ & & & & $\mathrm{mg} / \mathrm{kg}^{*}$ & \\
\hline F. gnaphalocarpa & 0.172 & 2.333 & 0.612 & 0.210 & 0.028 & 9.4 & 81.8 & 25.6 \\
$\quad$ I. senegalensis & 0.119 & 1.057 & 0.309 & 0.138 & 0.018 & 8.2 & 71.2 & 10.1 \\
C. pinnata (lot 1) & 0.137 & 2.471 & 0.046 & 0.079 & 0.011 & 3.5 & 41.0 & 8.7 \\
C. pinnata (lot 2) & 0.121 & 1.729 & 0.025 & 0.055 & 0.010 & 3.4 & 46.9 & 3.9 \\
C. pinnata (lot 3) & 0.139 & 1.684 & 0.045 & 0.075 & 0.011 & 4.1 & 19.0 & 7.7 \\
S. latifolius (lot 1) & 0.214 & 0.939 & 0.472 & 0.154 & 0.013 & 9.1 & 54.7 & 19.2 \\
S. latifolius (lot 2) & 0.209 & 0.884 & 0.518 & 0.156 & 0.011 & 8.9 & 184 & 22.7 \\
\hline
\end{tabular}

*In dry matter.

Table 5. Mineral comparison of the forest fruits in this study with other more recognized.

\begin{tabular}{|c|c|c|c|c|c|c|c|c|}
\hline & $\mathbf{P}$ & $\mathbf{K}$ & Ca & Mg & $\mathrm{Na}$ & $\mathrm{Cu}$ & $\mathbf{F e}$ & Zn \\
\hline samples & \multicolumn{5}{|c|}{$\mathrm{g} / 100 \mathrm{~g}^{*}$} & \multicolumn{3}{|c|}{$\mathrm{mg} / \mathrm{kg} *$} \\
\hline F. gnaphalocarpa & 0.172 & 2.333 & 0.612 & 0.210 & 0.028 & 9.4 & 81.8 & 25.6 \\
\hline I. senegalensis & 0.119 & 1.057 & 0.309 & 0.138 & 0.018 & 8.2 & 71.2 & 10.1 \\
\hline C. pinnata (lot 1) & 0.137 & 2.471 & 0.046 & 0.079 & 0.011 & 3.5 & 41.0 & 8.7 \\
\hline C. pinnata (lot 2) & 0.121 & 1.729 & 0.025 & 0.055 & 0.010 & 3.4 & 46.9 & 3.9 \\
\hline C. pinnata (lot 3) & 0.139 & 1.684 & 0.045 & 0.075 & 0.011 & 4.1 & 19.0 & 7.7 \\
\hline S. latifolius (lot 1) & 0.214 & 0.939 & 0.472 & 0.154 & 0.013 & 9.1 & 54.7 & 19.2 \\
\hline S. latifolius (lot 2) & 0.209 & 0.884 & 0.518 & 0.156 & 0.011 & 8.9 & 184 & 22.7 \\
\hline A. digitata [29] & 0.035 & 1.742 & 0.269 & 0.139 & 5.1 & 0.5 & 8.2 & 0.8 \\
\hline Z. mauritiana [30] & 0.26 & nd & $0.47 \%$ & $0.11 \%$ & nd & nd & 49 & nd \\
\hline M. pseudopetalosa [33] & 0.166 & 1.142 & 0.039 & 0.059 & 205 & nd & 41.2 & nd \\
\hline
\end{tabular}

*In dry matter; nd: non determined.

cially in S. latifolius (1488 $\mathrm{mg} / 100 \mathrm{~g})$; ensure non neglected contributing in copper, zing in S. latifolius, F. gnaphalocarpa and I. senegalensis; and constitute a good caloric source particularly in C. pinnata $(177 \mathrm{kcal} / 100 \mathrm{~g})$. For a better appreciation of the vitamin $\mathrm{C}$, total phenolic content, total flavonoid content related to the antioxidant power can be measured. In addition, a comparative study of different activities expressed as DPPH radical scavenging activity, ferric reducing antioxidant power value and ascorbic acid equivalent anti-oxidant seems necessary. Therefore, researches in this area are conducting and the results will be published soon. Apart these positive contributions for food consumption of these forest fruit, many medicinal virtues have been recognized from reports or previous works. Thus, valorization and prevention of this biodiversity are particularly necessary for
C. pinnata in which climatic hazard represents a serious threat for the high and economic potentiality in wood production.

\section{REFERENCES}

[1] Food and Agriculture Organization, "Etude de la Filière des Produits Forestiers de Cueillette," FAO, PROjet de GEstion Durable et participative des énergies traditionnelles et de substitution (PROGEDE), 1999.

[2] Ministere de l'Environnement et de la Protection de la Natur, "Politique Forestière du Sénégal pour 2005-2025," 2005.

http:/www.fao.org/forestry/15132-0a9d7bd3b848771f0d 9522338fd799be4.pdf

[3] A. Kalinganire, J. C. Weber, A. Uwamariya and B. Kone, "Improving Rural Livelihoods through Domestication of Indigenous Fruit Trees in the Parklands of the Sahel," In: F. 
K. Akinnifesi, Ed., Indigenous Fruit Trees in the Tropics: Domestication, Utilization and Commercialization, CAB International, London, 2007, pp. 186-203. doi:10.1079/9781845931100.0186

[4] B. Koné, A. Kalinganire and M. Doumbia, "La Culture du Jujubier: Un Manuel Pour l'Horticulteur Sahélien," Manuel Technique No. 10, World Agroforestry Center, 2009.

[5] Food and Agriculture Organization, "Importance des PFNL dans la Sécurité Alimentaire au Sénégal Rapport Préliminaire," FAO, Accra, 1999.

[6] C. O. Perera and E. A. Baldwin, "Biochemistry of Fruits and Its Implications on Processing," In: D. Arthey and P. R. Ashurst, Eds., Fruit Processing: Nutrition, Products, and Quality Management, Aspen Publishers, Gaithersburg, 2001, pp. 25-27.

[7] E. Faye, M. Diatta, A. N. S. Samba and J. Lejoly, "Usages et Dynamique de la Flore Ligneuse dans le Terroir Villageois de Latmingué (Sénégal)," Journal des Sciences et Technologies, Vol. 7, No. 1, 2008, pp. 43-58.

[8] C. T. Allemande, "Plan d'Aménagement et de Gestion Sylvo-Pastorale de la Forêt Classée de Dankou," Edition GTZ, Dakar, 2005.

http://www.peracod.sn/IMG/pdf/PLAN-AMENAGEME NT-FORET-DANKOU-SEPT2005.pdf

[9] J. Giner, V. Gimeno, A. Espachs, P. Elez, G. V. BarbosaCánovas and O. Martín, "Inhibition of Tomato (Licopersicon esculentum Mill.) Pectin Methylesterase by Pulsed Electric Fields," Innovative Food Science \& Emerging Technologies, Vol. 1, No. 1, 2000, pp. 57-67. doi:10.1016/S1466-8564(00)00003-5

[10] A. Samba, C. Camire and H. A. Margolis, "Allometry and Rainfall Interception of Cordyla Pinnata in a Semi-arid Agroforestry Parkland, Senegal," Forest Ecology and Management, Vol. 154, No. 1-2, 2001, pp. 277-288. doi:10.1016/S0378-1127(00)00633-2

[11] S. M. Keita, J. T. Arnason, B. R. Baum and R. Marles, "Etude Ethnopharmacologique Traditionnelle de Quelques Plantes Médicinales Anthelminthiques de la Haute-Guinée (République de Guinée)," Revue de Médecines et Pharmacopées Africaines, Vol. 13, 1999, pp. 49-65.

[12] M. N'Diaye, F. B. Kéita and P. Martin, "Principaux Fruits de Cueillette Consommés et Commercialisés en Guinée," Fruits, Vol. 58, No. 2, 2003, pp. 99-116.

[13] P. Soloviev, T. D. Niang, A. Gaye and A. Totte, "Variabilité des Caractères Physico-chimiques des Fruits de Trois Espèces Ligneuses de Cueillette Récoltés au Sénégal: Adansonia Digitata, Balanites Aegyptiaca et Tamarindus Indica," Fruits, Vol. 59, No. 2, 2004, pp. 109-119. doi:10.1051/fruits:2004011

[14] S. M. Itef, "Séminaire sur les Statistiques Forestières en Afrique," Food and Agriculture Organization, Thiès, 1991.

[15] G.-A. Ambé, "Les Fruits Sauvages Comestibles des Savanes Guinéennes de Côte-d'Ivoire: Etat de la Connaissance par Une Population Locale, les Malinké," Biotechnology, Agronomy, Society and Environment, Vol. 5, No. 1, 2001, pp. 43-58.
[16] Union Internationale pour la Conservation de la Nature, "Soutien Informationnel aux Politiques, de Conservation, de Gestion et d'Utilisation des Plantes Médicinales au Sénégal," Edition UICN, Dakar, 2006.

[17] M. Cissé, M. Sakho, M. Dornier, C. M. Diop, M. Reynes and O. Sock, "Caractérisation du Fruit du Baobab et Etude de sa Transformation en Nectar," Fruits, Vol. 64, No. 1, 2009, pp. 19-34.

[18] D. A. Gabar, M. Sakho, M. Dornier, M. Cissé and M. Reynes, "Le Baobab Africain (A. digitata L.): Principales Caractéristiques et Utilisations," Fruits, Vol. 61, No. 1, 2006, pp. 55-69.

[19] M. Muchuweti, G. Zenda, A. R. Ndhlala and A. Kasiyamhuru, "Sugars, Organic Acid and Phenolic Compounds of Ziziphus Mauritiana Fruit," European Food Research \& Technology, Vol. 221, No. 3-4, 2005, pp. 570-574. doi:10.1007/s00217-005-1204-6

[20] F. D. Ugese, P. K. Baiyeri and B. N. Mbah, "Nutritional Composition of Shea (Vitellaria paradoxa) Fruit Pulp Across Its Major Distribution Zones in Nigeria," Fruits, Vol. 63, No. 3, 2008, pp. 163-170. doi:10.1051/fruits:2008006

[21] E. A. Abdel-Rahim, S. S. El-Saadany and M. M. Wasi "Biochemical Action of Balanites Aegyptiaca Fruits as Possible Hypoglycemic Agent," Food Chemistry, Vol. 19, No. 4, 1986, pp. 307-315. doi:10.1016/0308-8146(86)90054-3

[22] Association Francaise de Normalisation, "Produits Dérivés des Fruits et Légumes, Jus de Fruits," Éd. Association Francaise de Normalisation, Paris, 1982.

[23] M. Cissé, "Caractérisation de Quelques Fruits du Sénégal, Stabilisation et Concentration de Jus de Fruits Tropicaux par des Techniques Membranaires," Thèse de Doctorat, Université Cheikh Anta Diop de Dakar, Dakar, 2007.

[24] P. Danthu, P. Soloviev, A. Totté, E. Tine, N. Ayessou, A. Gaye, T. D. Niang, M. Seck and M. Fall, "Caractères Physico-chimiques et Organoleptiques Comparés de Jujubes Sauvages et des Fruits de la Variété Gola Introduite au Sénégal,” Fruits, Vol. 57, No. 3, 2001, pp. 173-182. doi:10.1051/fruits:2002016

[25] C. Grollier, C. Debien, M. Dornier and M. Reynes, "Principales Caractéristiques et Voies de Valorisation du Tamarin," Fruits, Vol. 53, No. 4, 1998, pp. 271-280.

[26] S. W. Souci, W. Fachmann and H. Kraut, "Food Composition and Nutrition Tables," MedPharm, Stuttgart, 2008.

[27] N. C. Ayessou, M. Gueye, E. Dioh, M. Konteye, M. Cissé and M. Dornier, "Composition Nutritive et Apport Energétique du Fruit de Maerua pseudopetalosa, Aliment de Soudure au Sénégal," Fruits, Vol. 64, No. 3, 2009, pp. 147-156. doi:10.1051/fruits/2009010

[28] C. F. Bourgeois, "Les Vitamines dans les Industries Agroalimentaires," TEC et DOC, Paris, 2002.

[29] R. B. Rodriguez, H. C. Menezes, L. M. C. Cabral, M. Dornier, G. M. Rios and M. Reynes, "Evaluation of Reverse Osmosis and Osmotic Evaporation to Concentrate Camu-Camu Juice (Myrciaria dubia)," Journal of Food Engineering, Vol. 63, No. 1, 2004, pp. 97-102. 
doi:10.1016/i.jfoodeng.2003.07.009

[30] J. Graumlich, T. M. Ludden, C. Conry-Cantilena, L. R. Cantilena, Y. Wang and M. Levine, "Pharmacokinetic Model of Ascorbic Acid in Humans during Depletion and Repletion," Pharmaceutical Research, Vol. 14, No. 9, 1997, pp. 1133-1139. doi:10.1023/A:1012186203165

[31] J. Kubola, S. Siriamornpun and N. Meeso, "Phytochemicals, Vitamin C and Sugar Content of Thai Wild Fruits," Food Chemistry, Vol. 126, No. 3, 2011, pp. 972-981. doi:10.1016/j.foodchem.2010.11.104
[32] K. H. Schmidt, V. Hagmaier, D. H. Hornig, J. Vuilleumier and G. Rutishauser, "Urinary Oxalate Excretion after Large Intakes of Ascorbic Acid in Man," The American Journal of Clinical Nutrition, Vol. 34, No. 3, 1981, pp. 305-311.

[33] M. Levine, "New Concepts in the Biology and Biochemistry of Ascorbic Acid," The New England Journal of Medicine, Vol. 314, No. 14, 1986, pp. 892-902. doi:10.1056/NEJM198604033141407

[34] Food and Agriculture Organization, "Human Vitamin and Mineral Requirements,” FAO/WHO, Bangkok, 1998. 